\title{
EUTHANASIA DALAM PANDANGAN MORAL, KODE ETIK KEDOKTERAN DAN PERSPEKTIF HUKUM ISLAM
}

\author{
Zilfania Rahmawati \\ Institut Agama Islam Negeri Kudus, ozilfakhan7@gmail.com \\ Ashif Az Zafi \\ Institut Agama Islam Negeri Kudus, ashifarzafi@iainkudus.ac.id
}

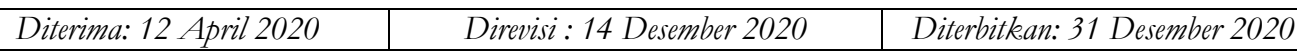

\begin{abstract}
(c) (1) (2)
(C)2020 by the authors. Submitted for possible open access publication under the terms and conditions of the Creative Commons Attribution (CC-BY-SA) license (https://creativecommons.org/licenses/by-sa/4.0/) do) DOI : 10.30983 /alhurriyah.v5i2.3205
\end{abstract}

\begin{abstract}
The practice of euthanasia in medicine has become a topic that raises various discussions when viewed from different points of view. The existence of differences of opinion that arise from the practice of euthanasia is normal because the practice is related to buman life. Based on this, this scientific study aims to determine euthanasia from a moral perspective, a medical code of ethics and in the perspective of Islamic law. The process of collecting data from scientific studies was carried out by means of literature research using qualitative descriptive methods in presenting and analyzing the data obtained. The results of the study show how euthanasia practices are in accordance with the medical code of ethics, moral views and how the law is in Islam.
\end{abstract}

Keywords: Euthanasia, Medicine, Morals, Islamic Law

\begin{abstract}
Abstrak
Praktik Euthanasia dalam kedokteran menjadi hal yang menimbulkan berbagai perbincangan bila dilihat dari sudut pandang yang berbeda. Adanya perbedaan pendapat yang muncul dari praktik euthanasia merupakan suatu kewajaran karena praktik tersebut berbubungan dengan nyawa manusia. Berdasarkan hal tersebut studi ilmiah ini bertujuan untuk mengetabui euthanasia dalam pandangan moral, kode etik kedokteran dan dalam perspektif bukum Islam. Proses pengumpulan data studi ilmiah ini dilakukan dengan cara penelitian literatur menggunakan metode deskriptif kualitatif dalam penyajian dan anlisis data yang diperoleh. Hasil dari penelitian menunjukkan bagaimana praktik euthanasia yang sesuai kode etik. kedokteran, pandangan moral dan bagaimana hukumnya dalam agama Islam.
\end{abstract}

Kata Kunci : Euthanasia, Kedokteran, Moral, Hukum Islam

\section{PENDAHULUAN}

Pada perkembangan ilmu pengetahuan dan IpTek yang sangat pesat di zaman sekarang ini, khususnya dalam bidang kedokteran. Hal itu ditandai dengan berbagai tindakan atau pelayanan yang semakin canggih dan berkualitas yang diberikan bagi pasien. Seiring berkembangnya hal tersebebut, muncul suatu praktik dalam kedokteran yang disebut euthanasia. Munculnya praktik euthanasia berdasarkan adanya konsep tentang kematian. Ilmu pengetahuan membagi kematian menjadi tiga golongan berdasarkan cara terjadinya yaitu kematian alamiah (orthothanasia), kematian tidak wajar (dysthanasia) dan kematian direncanakan (euthanasia). 
Euthanasia merupakan tindakan sengaja merencanakan kematian seseorang atau pasien tanpa rasa sakit, untuk menghilangkan penderitaan yang dialami. ${ }^{1}$

Dalam praktik euthanasia di dunia kedokteran dianggap menjadi hal positif karena bertujuan meringankan penderitaan pasien. Tetapi, tak sedikit pula yang menimbulkan berbagai perspektif negatif dikalangan masyarakat yang melihat praktik euthanasia dari sudut pandang yang berbeda. Pada contoh kasus seorang penderita kanker ganas yang merasakan sakit luar biasa. Dalam hal ini, dokter memiliki keyakinan bahwa pemberian obat dengan dosis tinggi akan menghentikan sakitnya sekaligus menghilangkan nyawanya. Sehingga hilanglah penderitaan pasien tersebut. Tetapi hal itu akan menimbulkan suatu permasalahan atau perbedaan pendapat jika dilihat dari kesesuain dengan moral kemanusiaan, ataupun dari segi perspektif hukum Islam. Perspektif negatif yang timbul dapat berupa anggapan bahwa praktik euthanasia dilakukan karena faktor perekonomian yang lemah. Sehingga praktik euthanasia dilakukan untuk meminimalisir biaya pengobatan yang dikeluarkan. Hal tersebut yang menjadikan salah satu alasan bahwa euthanasia tidak sesuai dengan moral kemanusiaan. Sedang dalam prinsip hukum Islam sengaja mengakhiri hidup atau mempercepat kematian orang yang sakit termasuk kategori

\footnotetext{
${ }^{1}$ Setiawan Budi Utomo, FIQIH AKTUAL (jakarta: GEMA INSANI PRESS, 2003), 176.
}

mendahului takdir atau ketentuan dari Allah SWT. Mengenai bagaimana ketentuan praktik euthanasia yang sesuai kode etik kedokteran, pandangan moral, dan dalam perspektif hukum islam yang akan di paparkan dalam bagian pembahasan.

\section{PEMBAHASAN}

\section{Euthanasia Dalam Kode Etik Kedokteran}

Euthanasia berasal dari bahasa yunani yaitu kata "eu" artinya baik dan "thonetos" artinya mati. Jadi, euthanasia memiliki arti mati sentosa atau mati bahagia karena tanpa rasa sakit. Hal yang membuat mati tanpa rasa sakit dan terlepas dari penderitaan. Sehingga euthanasia merupakan pembunuhan yang dilakukan dengan sengaja terhadap seseorang atau pasien yang memiliki harapan kecil untuk hidup atau sembuh kembali. Sedangkan pada Ensiklopedi Nasional Indonesia memaparkan bahwa euthanasia diartikan dengan sengaja mengakhiri kehidupan seseorang supaya terbebas dari kesengsaraaan dari sakit yang diderita. Euthanasia umumnya dilakukan pada pasien yang sudah tidak memiliki harapan sembuh, namun masih bertahan hidup dengan penyakit yang diderita. Pada kamus kesehatan menerangkan euthanasia adalah tindakan mencabut nyawa seseorang, mengakhiri dengan sengaja kehidupan secara tenang dan mudah untuk meakhiri penderitaan. Euthanasia juga diartikan "a good death" atau mati dengan tenang. Hal 
itu dapat diwujudkan atas permintaan pasien atau keluarganya karena penderitaan yang sangat hebat dan tiada akhir, atau juga membiarkan seseorang yang sedang sakit tanpa memberikan pengobatan atau pertolongan.

Kode etik kedokteran Indonesia, mengartikan eutanasia dalam tiga arti yaitu berpindahnya ke alam baka yang tenang dan aman, saat sakaratul maut penderitaan si sakit diringankan dengan memberikan obat penenang, mengakhiri penderitaan sekaligus kehidupan seseorang yang sakit dengan sengaja atas permintaan pasien sendiri atau keluaganya. ${ }^{2}$ Dilihat dari segi tindakan yang dilakukan oleh pelaku, euthanasia dibagi dua yaitu euthanasia indirect (pasif), merupakan euthanasia yang dilakukan tanpa memberikan perawatan ataupun dengan cara menghentikan pengobatan yang berpotensi memperpanjang hidup pasien. Contohnya, petugas medis tidak memberikan penanganan semisal memasang alat bantu pernapasan pada penderita kanker yang sudah kritis, pasien koma, disebabkan benturan di bagian kepala atau menderita penyakit pada otak dan tidak ada harapan untuk sembuh.

Beberapa bentuk euthanasia pasif adalah menarik perawatan medis dari pasien yang sakit parah, menahan perawatan medis dari pasien yang sakit parah, obat pereda nyeri yang dapat

${ }^{2}$ Direktorat Jenderal Kesehatan, Kode Etik Kedokteran Indonesia (Jakarta: Departemen Kesehatan, 1983), 26. mempercepat kematian pasien yang sakit parah sebagai efek samping, menghentikan sistem pendukung kehidupan seperti ventilator, menolak perawatan medis untuk pasien yang sakit parah.

Mercy Killing (aktif), yaitu euthanasia dengan cara sengaja mememberikan tindakan yang dapat mempercepat kematian seseorang. Contoh, pada penderita kanker ganas yang merasakan sakit luar biasa hingga sering pingsan. Hal ini dokter berkeyakinan bahwa pasien tidak mampu bertahan lebih lama lagi. Kemudian dokter memberi obat dengan dosis tinggi (overdosis) yang dapat menghilangkan rasa sakit yang dialami, dengan kata lain menghentikan nafasnya juga.

Dari segi korban, euthanasia dibagi tiga macam yaitu voluntary euthanasia (sukarela), merupakan tindakan euthanasia yang dikehendaki sendiri. Non voluntary euthanasia (diandaikan), merupakan tindakan euthanasia yang tidak diminta secara tegas oleh korban dengan kata lain dapat memilih atau meminta untuk dilakukan tindakan euthanasia, involuntary euthanasia (dipaksakan), tindakan euthanasia ini memang dilakukan terhadap pasien dengan kondisi sadar, tetapi dilakukan tanpa persetujuannya.

Mengenai konsep tentang kematian, pada tahun 1990 IDI (Ikatan Dokter Indonesia) bersepakat memberikan pernyataan bahwa manusia dikatakan mengalami kematian jika batang otaknya sudah 
tidak berfungsi lagi. Kriteria kemtian tersebut berdasar pada teori bahwa batang otak sebagai pusat penggerak pernafasan dan jantung. Sehingga matinya batang otak mengakibatkan paru-paru dan jantung tidak bisa berfungsi kecuali menggunakan alatalat penopang. ${ }^{3}$ Peryataan tentang hak untuk mati timbul karena penderitaan akibat penyakit yang diderita pasien tidak kunjung mereda meskipun telah ditemukannya teknologi canggih dalam bidang kedokteran untuk menangani pasien. Rasa sakit yang terus-menerus berkelanjutan tersebut yang akan membuat pasien maupun pihak keluarga putus asa dari segi moral ataupun materiil. Sehingga pada akhirnya, memutuskan untuk mempercepat kematian (euthanasia) sebab rasa sakit yang tidak tertahankan lagi.

Dalam melakukan euthanasia harus mengikuti prosedur dan proses panjang yang menjadi ketentuan dalam tindakan euthanasia. Sebagai contoh yaitu Belanda sebagai negara pertama yang melegalkan tindakan euthanasia pada tahun 2001, seseorang yang akan melakukan euthanasia harus mengajukan permohonan dan akan mendapatkan konseling dari psikolog. Kemudian pasien diberi waktu untuk berfikir kembali yang disebut waiting periode. Setelah menentukan keputusan, permohonan harus mendapatkan sertifikat atau persetujuan setidaknya dari dua orang

${ }^{3}$ M. Yusup and Amri Amir, Teknologi Kedokteran Dan Tantangannya Terbadap Biotike (Jakarta: Gramedia Pustaka Utama, n.d.), 105. dokter yang menyatakan bahwa pasien memang benar-benar kecil kemungkinan untuk tertolong. Setelah semua proses tersebut dilewati, barulah kemudian mengajukan permohonan ke pengadilan untuk memperoleh persetujuan. Setahun kemudian negara Belgia yang melegalkan euthanasia. Berbeda dengan Belanda dan Belgia, di Swiss tindakan euthanasia masih dianggap legal padahal di negera tersebut ada tiga organisasi yang menaungi permohonan euthanasia. Didalamnya melayani konseling masalah euthanasia dan menyediakan obat-obatan yang memang difungsikan untuk praktik euthanasia. Tetapi, pemerintah Swiss melarang tindakan euthanasia menggunakan suntikan. Sehingga seseorang yang mengajukan permohonan euthanasia harus diinfokan ke polisi.

Di wilayah Asia, jepang adalah satu-satunya negara yang pernah melegalkan praktik tergolong voluntary eutanasia pada tahun 1962 dalam kasus Yanaguchi dan disahkan oleh pengadilan tinggi. Tetapi karena kuatnya kebudayaan, tidak ada lagi praktik euthanasia yang dilakukan. Sementara di Amerika, sejak adanya Death With Dignity Law pada tahun 1994 dan tercatat ada 100 orang berada dalam tahap lanjut proses pengajuan tetap saja tindakan euthanasia dilegalkan dan masih diperdebatkan.

Beberapa motivasi dilakukannya tindakan euthanasia dantaranya adalah faktor ekonomi, 
biaya pengobatan yang semakin mahal dan keadaan ekonomi yang mulai rendah menjadikan tindakan euthanasia ditempuh untuk meminimalisir pengeluaran biaya. Pertimbangan ruangan, tempat tidur, petugas, dan peralatan medis dirumah sakit yang justru dapat dimanfaatkan oleh pasienpasien yang lain. Mati yang layak, konsep mati dengan layak telah melahirkan gerakan perumah sakitan di Inggris, pasien - pasien berpenyakit parah yang dirawat di rumah sakit di seluruh dunia diberi kesempatan untuk memilih hidup dengan layak atau mati dengan layak. Artinya, para pasien yang sekarat itu diberi kesempatan seluas-luasnya untuk menikmati apa yang mereka inginkan daripada berbaring di tempat tidur. Konsep tentang rasa sakit dan penderitaan. ${ }^{4}$

Umumnya manusia ingin segera terbebas dari rasa sakit atau penderitaan yang dirasakannya. penderitaan pasien yang tetap berkelanjutan, walau sekalipun di temukannya teknologi canggih, namun penderitaan tidak dapat dihilangkan sama sekali. Penderitaan yang berkelanjutan ini menyebabkan pasien atau keluarga pasien kadang-kadang tidak mampu untuk menanggungnya baik moril maupun materiil. Oleh karena itu, mungkin pasien ataupun keluarganya menginginkan agar hidupnya diakhiri apabila sudah sampai pada klimaks penderitaan yang tidak tertahankan lagi. Beberapa faktor

\footnotetext{
${ }^{4}$ Muhammad Vandestra, Hukum Bunuh Diri Dan Eutanasia Dalam Syariah Islam (Copyright, 2018), 16-17.
}

penyebab dilakukannya praktik euthanasia menurut F. Tengker yaitu Pada bayi yang baru lahir atau neonatus, yang dirundung cacat fisik berat dimana nivo pemikiran tidak lebih luas dari naluri, Mereka yang lumpuh total akibat kecelakaan atau para lanjut usia yang fungsi kejiwaannya masih utuh, namun keadaan fisik mereka telah renta yang menyebabkan ketidakmampuan mereka untuk lebih lama bertahan dalam lingkungan hidup, adanya suatu pertimbangan dan pemikiran bahwa kematian sudah diambang pintu dan kehidupan telah diakhiri seutuhnya setelah sekian lama mengalami penderitaan yang dahsyat dan tidak tertahan lagi, dunia kedokteran melakukan atas dasar kemanusiaan terhadap sesama manusia yang menderita penyakit yang tidak dapat lagi disembuhkan, dilakukan karena motif ketakutan akan penderitaan yang dialami, kemiskinan dan beban hidup. ${ }^{5}$

\section{Melihat Euthanasia Dari Segi Moral Kemanusiaan}

Tindakan penanganan yang diberikan kepada pasien merupakan suatu hal yang bernilai penting. Dalam hal tersebut penanganan yang diberikan haruslah dapat dipertanggungjawabkan, baik dari segi kedokteran, hukum, maupun dari segi peraturan moral kemanusiaan yang sesuai. Seiring berkembangnya ilmu pengetahuan dibidang kedokteran, harus memperhatikan kodrat

\footnotetext{
${ }^{5}$ F. Tengker, Mengapa Euthanasia? Kemampuan Medis Dan Konsekuensi Yuridis (Bandung: Nova, 1990), 23.
} 
danmartabat manusia serta lingkungan dan bersifat universal sehingga dapat memperkokoh eksistensi manusia. Disinilah peran etika atau moral diperlukan dalam mengimbangi kemajuan dalam ilmu pengetahuan tersebut. ${ }^{6}$

Moral merupakan sekumpulan nilai dalam kehidupan yang mengatur tingkan laku sesorang atau kelompok. Tingkah laku tersebut mewujudkan moralitas yang menjadi kebiasaan yang telah diterima atau disepakati bersama dalam masyarakat tanpa adanya proses permusyawaratan. Sedangkan moral dalam hubungan antara dokter dengan pasien, ada 4 kaidah dasar moral yang mengaturnya yaitu dokter wajib menghormati hak dan martabat pasien sebagai manusia (prinsip otonom), dokter harus mengutamakan tindakan yang ditujukan untuk kebaikan pasien atau menyembuhkannya (prinsip beneficience), dokter tidak melakukan tindakan yang memperburuk keadaan pasien dan memberikan penanganan pengobatan yang berisiko paling kecil bagi pasien (prinsip non-malficience), dokter memberikan tindakan penanganan tiap pasien dengan adil (prinsip justice).

Mengenai praktik tindakan euthanasia dalam menangani pasien yang juga merupakan perkembangan IpTek di dunia kedokteran, menjadikan tindakan tersebut harus memiliki hukum atau aturan yang jelas dan dapat dipertanggungg jawabkan. Tindakan euthanasia menyangkut

\footnotetext{
${ }^{6}$ Achadiat, Eutanasia Yang Semakin Kontroversial (Jakarta: Terajana, 2002), 169.
}

kepentingan perlindungan pada nyawa perseorangan. Di Indonesia Buku II dan III KUHP telah mengatur tentang tindak pidana. Mengenai euthanasia diatur dalam pasal 344 KUHP Bab XIX yang berbunyi :

"Siapa yang merampas nyawa seseorang atas permintaan orang itu sendiri dan dinyatakan dengan kesungguhan hati diancam pidana penjara paling lama 12 tahun".

Hal itu karena euthanasia merupakan tindakan yang berhubungan dengan penghilangan nyawa.Pasal tersebut dapat dijadikan sumber hukum yang mengatur euthanasia di Indonesia. Tetapi pasal 344 KUHP belum pernah menjaring euthanasia sebagai tindakan pidana. Hal ini dikarenakan sulitnya pembuktian dalam isi rumusan pasal tersebut yaitu pada kalimat "atas permintaan sendiri” serta kalimat "yang dinyatakan dengan kesungguhan hati". Oleh karena dalam kenyataannya Pasal 344 KUHP sulit untuk diterapkan sehingga muncul suara-suara yang mengatakan " sebaiknya redaksi Pasal 344 KUHP dirumuskan kembali berdasarkan kenyataan kenyataan yang terjadi sekarang dan dimasa mendatang, yang disesuaikan dengan perkembangan medis ". Dengan rumusan baru ini diharapkan dapat memungkinkan atau memudahkan penanganan

\footnotetext{
${ }^{7}$ Adami Chazawi, Kejabatan Terbadap Tubub Dan Nyawa (Jakarta: PT. Raja Grafindo Persada, 2001), 102.
} 
kasuskasus euthanasia dengan hukum pidana. ${ }^{8}$

Sampai saat ini, kaidah non hukum yang manapun, baik agama, moral, dan kesopanan menentukan bahwa membantu orang lain mengakhiri hidupnya, meskipun atas permintaan yang bersangkutan dengan nyata dan sungguh-sungguh adalah perbuatan yang tidak baik. Negara yang telah memberlakukan euthanasia lewat undang-undang adalah Belanda dan di negara bagian Oregon-Amerika Serikat. Di Amerika Serikat, euthanasia lebih populer dengan istilah "Physician asisted suicide". Pelaksanaannya dapat dilakukan dengan syarat-syarat tertentu antara lain orang yang ingin diakhiri hidupnya adalah orang yang benarbenar sakit dan tidak dapat diobati, pasien berada dalam keadaan terminal, kemungkinan hidupnya kecil dan tinggal menunggu kematian, pasien harus menderita sakit yang amat sangat, sehingga penderitaannya hanya dapat dikurangi dengan pemberian morfin, yang boleh melaksanakan bantuan pengakhiran hidup pasien, hanyalah dokter keluarga yang merawat pasien dan ada dasar penilaian dari dua orang dokter spesialis yang menentukan dapat tidaknya dilaksanakan euthanasia. Semua persyaratan itu harus dipenuhi, baru euthanasia dapat dilaksanakan. Indonesia sebagai negara berasaskan Pancasila, dengan sila pertamanya 'Ketuhanan Yang Maha Esa', tidak

${ }^{8}$ Moch Anwar, Hukum Pidana Bagian Khusus (KUHP Buku II) (Bandung: Alumni KP, 1979), 272. memungkinkan menerima tindakan “eutanasia aktif”. Mengenai “eutanasia pasif", merupakan suatu "daerah kelabu" karena memiliki nilai bersifat "ambigu" yaitu di satu sisi bisa dianggap sebagai perbuatan amoral, tetapi di sisi lain dapat dianggap sebagai perbuatan mulia karena dimaksudkan untuk tidak memperpanjang penderitaan atau berjalan secara alamiah. ${ }^{9}$ Dalam pandangan etika atau moral kemanusiaan tindakan euthanasia berhadapan pada prinsip menghargai kehidupan manusia. Bagaimanapun keadaan hidupnya tindakan euthanasia tidak dibenarkan karena termasuk pembunuhan.

\section{Euthanasia Dalam Perspektif Hukum Islam}

Dalam era modern ini, perkembangan ilmu pengetahuan dan IpTek semakin pesat. Sehingga banyak mengakibatkan berbagai perubahan kehidupan sosial budaya manusia disebabkan adanya teknologi modern yang ditujukan untuk kepentingan manusia. Dunia kedokteran tak lepas dari perkembangan ilmu pengetahuan dan IpTek dalam memberikan pelayanan yang terbaik bagi pasiennya. Betapapun majunya ilmu pengetahuan dibidang kedokteran tetatpi masih ada pasien yang tak terhindarkan dari penderitaan yang berat, baik fisik maupun mental. Sehingga persoalan tersebut tersebut membutuhkan tindakan penanganan atau jalan keluar

\footnotetext{
${ }^{9}$ Indar et al., Hukum \& Bioetik Dalam Perspektif Etika Dan Hukum Kesehatan (Yogyakarta: Deepublish, 2019), 30.
} 
yang lebih sempurna. Dalam dunia kedokteran terdapat suatu praktik atau tindakan yang diberikan kepada pasien yang disebut dengan euthanasia, yang dalam bahasa Arab dinamakan Qatl arRabmah atau Taisir al-Maut. Yaitu Tindakan memudahkan kematian seseorang dengan sengaja tanpa merasakan sakit, karena kasih sayang, dengan tujuan meringankan penderitaan si sakit, baik dengan cara positif ataupun negatif. ${ }^{10}$

Al Qur'an menjelaskan bahwa masalah kematian adalah rahasia Allah SWT. Manusia hanya berkewajiban untuk tetap menjaga, memelihara, menghargai, dan membela kehidupan sendiri maupun kehidupan orang lain. Surat Al-Israa' ayat 85 yang artinya :

Dan mereka bertanya kepadamu tentang roh. Katakanlah: " Roh itu termasuk urusan Tuhan-ku, dan tidaklah kamu diberi pengetahuan melainkan sedikit."

Dan dalam surat An-Nisaa' ayat 29-30 yang artinya :

"Hai orang-orang yang beriman, janganlah kamu saling memakan harta sesamamu dengan cara yang batil, kecuali dengan jalan perniagaan yang berlaku dengan suka sama suka diantara kamu. Dan janganlah kamu membunuh dirimu sesungguhnya Allah Maha Penyayang kepadamu. Dan barangsiapa berbuat demikian dengan melanggar hak dan aniaya, maka kami kelak akan

\footnotetext{
${ }^{10}$ Yusuf Qordlawi, Fatwa-Fatwa Kontemporer, Jilid 2 Jakarta: GEMA INSANI PRESS, 2002), 752.
}

memasukkannya ke dalam neraka,yang demikian itu adalah mudah bagi Allah."11

Euthanasia atau yang dinamkan dengan Taisir al-Maut dalam islam dibagi menjdi dua yaitu Taisir al-Maut al-fa'al (euthanasia positif) dan Taisir alMaut al-Munfa'il (euthanasia negatif). Maksud dari Taisir al-fa'al ialah tindakan memudahkan kematian seorang yang sakit yang dilakukan oleh dokter dengan menggunakan instrumen (alat), Diantara contohnya yaitu seorang penderita kanker ganas yang merasakan kesakitan yang yang luar biasa dan sering pinsan. Dokter yakin bahwa pasien tersebut akan meniggal dunia. Kemudian dokter memberikan obat dengan takaran atau dosis yang tinggi (overdosis) dengan tujuan menghilangkan rasa sakit atau penderitaannya, tetapi sekaligus menghentikan pernapasannya dan seseorang yang dalam keadaan koma yang sangat lama. Dalam keadaan ini pasien hanya mungkin dapat hidup dengan menggunakan bantuan alat pernafasan. Namun biasanya, manusia beranggapan bahwa orang sakit seperti ini sebagai orang mati maka memberhentikan alat bantu pernafasannya sebagai cara yang positif untuk memudahkan proses kematian. Memudahkan proses kematian seperti pada contoh pertama tidak diperbolehkan dalam syara'. Sebab hal demikian berarti dokter melakukan tindakan penanganan dengan tujuan mempercepat

11 Gibtiah, Fikih Kontemporer (Jakarta: Kencana, 2016), 170. 
kematianpasien. Maka dalam hal ini, dokter telah melakukan pembunuhan meski dengan tujuan maksud yang baik. Namun tindakan tersebut termasuk pembunuhan dengan sengaja dan terencana yang bertentengan dengan syari'at Islam karena melanggar hak Allah SWT. ${ }^{12}$

Pada prinsip syari'at islam pembunuhan secara sengaja terhadap orang yang sakit berarti mendahului takdir. Hal itu karena yang berhak mematikan dan menghidupkan manusia hanyalah Allah dan manusia dalam hal ini tidak mempunyai hak atau kewenangan umtuk memberi hidup atau mematikannya. QS.Yunus ayat 56 yang artinya :

"Dia-lah yang menghidupkan dan yang mematikan dan hanya keada-Nya lah kamu dikembalikan."13

Berbeda dengan praktik Taisir al-fa'al, praktik Taisir al-munfa'il tidak menggunakan alat-alat atau langkahlangkah aktif untuk mengakhiri kehidupan seorang yang sakit. Tetapi hanya dibiarkan tanpa diberikan pengobatan. Misal pada contoh kasus orang yang menderita sakit paru-paru tidak yang jika tidak diobati padahal masih ada kemungkinan untuk dapat diobati akan dapat mematikan penderita. Dalam hal ini, jika pengobatan dihentikan dapat mempercepat kematian si penderita sakit. Kemudian pada kasus seorang yang menderita kelumpuhan dan tidak

${ }^{12}$ Hanafi Ahmad, Asas-Asas Hukum Pidana Islam, 1967, 19.

13 Setiawan Budi Utomo, FIQIH AKTUAL (Jakarta: GEMA INSANI PRESS, 2003), 179. melakukan pengobatan. Keadaan tersebut dapat menyebabkan ketidakmampuan untuk bertahan lebih lama dilingkungan hidup. ${ }^{14}$ Memudahkan proses kematian dengan menghentikan atau tidak memberikan pengobatan seperti pada contoh tersebut, berdasarkan kaidah hukum Islam hal itu adalah "la dharar wa la dirar" (tidak ada kerusakan dan tidak ada pengrusakan). Dikalangan ulama syara' masalah tersebut sudah terkenal. Menurut jumhur fukaha dan imamimam mazhab mengobati atau berobat dari penyakit tidak wajib hukumnya. Bahkan, menurut mereka berobat atau mengobati hanya berkisar pada hukum mubah. Hanya segolongan kecil yang mewajibkannya. Seperti dikatakan sahabat-sahabat Imam Syafi'i dan Imam Ahmad sebagaimana dikemukakan oleh Syekhul Islam Ibnu Taimiyah. "Dan sebagian ulama lagi menganggapnya mustahab (sunnah). ${ }^{15}$ Adapun ulama yang berpendapat bahwa penderita yang berpenyakit menular dan membahayakan orang lain jika dibiarkan hidup, hendaknya dilakukan alternatif tindakan lain selain euthanasia. Salah satunya adalah dengan mengisolasi penderita tersebut agar tidak berinteraksi dengan orang lain selama pengobatannya. Jikamemang dokter menyatakan pasien tidak dapat disembuhkan dengan cara apapun, hendaknya

\footnotetext{
${ }^{14}$ Gibtiah, Fikih Kontemporer (Jakarta: Kencana, 2016), 173.

15 Ibnu Taimiyah, Al-Fatawa Al-Kubra, Juz 4 (Kairo: Mathbah Kurdistan al-Ilmiah, n.d.), 260.
} 
diserahkan kembali kepada keluarganya bukan dengan mengakhiri hidupnya. Soal sakit, menderita dan tidak kunjung sembuh adalah qudratullah. Mempercepat kematian tidak dibenarkan karena tugas dokter adalah menyembuhkan, bukan membunuh. Begitu besarnya penghargaan Islam terhadap jiwa, sehingga segala perbuatan yang mengarah kepada tindakan untuk menghilangkan jiwa manusia akan diancam dengan hukuman qisas-diyat atau ta'zir. Dalam hubungan ini euthanasia, khususnya euthanasia aktif dapat dikategorikan kehidupan manusia, dan oleh karenanya pula hal tersebut merupakan perbuatan yang bertentangan dengan kehendak Allah SWT. ${ }^{16}$

Secara umum hukum Islam diamalkan untuk menciptakan kemaslahatan hidup dan kehidupan manusia, sehingga aturan diberikan secara rinci, khusus yang berkaitan dengan hukum pidana, Islam ditetapkan aturann yang ketat yaitu Qisas (pembunuhan), had dan diyat. QS: An-nisaa' ayat 93 yang artinya:

"dan barang siapa yang
membunuh seorang mu'min
dengan sengaja, maka
balasannya ialah jahannam,
kekal ia didalamnya dan Allah
murka kepadanya dan
mengutuknya
menyediakan azab yang besar
baginya".

\footnotetext{
${ }^{16}$ Halim, Hukum Pidana Syariah Islam Menurut Ajaran-Ablusunnah (Jakarta: Bulan Bintang, 1971), 42.
}

Syaikh Muhammad Yusuf al-Qardawi, sebagaimana dikutip oleh Akh. Fauzi Asri mengatakan, bahwa kehidupan manusia bukan menjadi hak milik pribadi, sebab dia tidak dapt menciptakan dirinya (jiwanya), organ tubuhnya, ataupun sel-selnya. Diri manusia pada hakekatnya adalah barang ciptaan yang diberikan Allah, oleh karenanya ia tidak boleh diabaikan, apalagi dilepaskan dari kehidupannya. Jadi jelaslah bahwa Islam tidak membenarkan seseorang yang sakit dan berkeinginan untuk mempercepat kematiannya, baik bunuh diri ataupun meminta dibunuh. ${ }^{17}$

Dalam falsafah hidup islam ada dimensi tersentral dalam rasa sakit dan penderitaan. Al-Qur'an memberitahu kia bahwa orang-orang yang mengklaim dirinya beriman kepada Allah SW'T tidak akan dibiarkan begitu saja sesudah memproklamasikan keimanannya itu: Apakah manusia itu mengira bahwa mereka akan dibiarkan sesudah mengatakan,

"kami telah beriman," sedangkan mereka tidak diuji lagi? (Q.S. Al-Ankabut, 29:2).

Al-Qur'an lebih lanjut mengatakan bahwa orang-orang yang beriman itu akan diuji dengan beragam cara: Dan sungguh akan kami berikan cobaan kepadamu dengan sedikit ketakutan, kelaparan, kekurangan harta, jiwa, dan buah-buahan dan berilah kabar

${ }^{17}$ Djazuli, Fikih Jinayah, Upaya Menanggulangi Kejahatan Dalam Islam (Jakarta: PT. Raja Grafindo Persada, 1997), 11. 
gembira kepada orang-orang sabar. (yaitu) orang-orang yang apabila ditimpa musibah, mereka mengatakan: "sesungguhnya kami adalah milik Allah dan kepadanyalah kami kembali."mereka itulah orang-orang yang mendapat keberkahan yang sempurna dan rahmat dari Allah, dan mereka itulah orang-orang yang mendapat petunjuk (Q.S. Al-Baqarah 2:155).

Jadi, dapat disimpulkan bahwa sebagai umat Islam haruslah menganggap penderitaan yang dialami baik akibat penyakit yang mematikan maupun yang ringan adalah sebagai ujian keimanan yang melatih kepasrahan kita kepada Allah sebagai sang pencipta. Bahkan, penderitaan yang dialami seorang muslim dapat menjadi sarana pelebur dosa-dosa kecil yang pernah dilakukan. Dalam islam tidak ada anggapan ataupun pernyataan mengenai mengakhiri hidup untuk menghilangkan penderitaan. Karena Allah sendiri telah berfirman bahwa tidak akan membebani (memberikan ujian) kepada hamba-Nya melebihi batas kemampuan seorang hamba yang terdapat pada Q.S. Al-Baqarah ayat 286. Serta seorang muslim memiliki keimanan akan adanya hari akhir yang merupakan kehidupan yang kekal dan abadi setelah dibangkitkan dari kematian. Sehingga dapat dengan sabar menahan penderitaan yang dirasakan karena memahami kehidupan dunia yang bersifat sementara.

\section{TINJAUAN EUTHANASIA}

KAJIAN

Beberapa paparan dari penulis lain dalam mengkaji tentang euthanasia. Pertama, Mahmud Adesina Ayuba (2016) dalam "Euthanasia: A Muslim's Perspective" memaparkan tentang kode etik dalam kedoketan, dokter dilarang mengambil bagian dalam mengakhiri kehidupan seseorang. Terutama berlaku untuk kasus-kasus berikut. Pembunuhan yang disengaja dari seseorang yang secara sukarela meminta agar hidupnya berakhir, bunuh diri yang dibantu dokter, pembunuhan yang disengaja pada bayi yang baru lahir dengan kelainan bentuk yang mungkin atau mungkin tidak mengancam kehidupan mereka. ${ }^{18}$ Kedua, Nunes R dan Rego G (2016) dalam "Euthanasia: A Challenge to Medical Ethics" menyajikan mengenai pemaparan dari pernyataan dari James Rachels dalam bukunya "The Elements of Moral Philosophy" menyatakan bahwa "euthanasia mungkin benar secara moral" dengan argumen sebagai berikut. Hal yang benar secara moral untuk dilakukan, pada setiap kesempatan, adalah apa pun yang akan menghasilkan keseimbangan kebahagiaan terbesar daripada ketidakbahagiaan, Paling tidak padabeberapa kesempatan, keseimbangan kebahagiaan terbesar atas ketidakbahagiaan dapat terjadi melalui pembunuhan dengan kasih sayang (eutanasia), Oleh karena itu,

\footnotetext{
${ }^{18}$ Mahmud Adesina Ayuba, "EUTHANASIA: A MUSLIM'S PERSPECTIVE," Scriptura, 2016, 1-13.
} 
setidaknya pada beberapa kesempatan, pembunuhan dengan kasih sayang (eutanasia) mungkin benar secara moral. ${ }^{19}$ Dalam hal ini ia melihat eutanasia dari sudut pandang kebahagiaan mutlak yang harus didapat oleh seseorang. Apabila ia menderita sakit parah atau ktitis kebahagiaannya otomatis akan hilang, maka agar terhindar dari penderitaan tersebut eutanasia menjadi pilihan untuk ditempuh. Ketiga, Prof Ali Kaya (2012) dalam "Euthanasia in Islamic Law With Respect to the Theory of Protecting Integrity of Body and Soul" memaparkan euthanasia adalah sejenis tindakan yang merusak integritas tubuh dan jiwa manusia. Masalah euthanasia dalam hukum Islam dapat diatasi dengan teori integritas tubuh dan jiwa.

Beberapa prinsip hukum utama yang memberi cara untuk membentuk pendapat tentang teori integritas tersebut diantaranya yaitu prinsip tidak dapat diganggu gugatnya kehidupan, dalam hukum Islam, integritas tubuh dan jiwa dijamin dengan menghukum mereka yang melakukan dosa besar membunuh. Dilarang membunuh manusia, kecuali ada pembenaran yang sah sesuai syariat. Dalam khotbah terakhir Nabi Muhammad (saw):

“ Sama seperti inibulan dan tanah ini tidak bisa diganggu gugat, darah Anda juga tidak bisa diganggu gugat hari ini."

\footnotetext{
19 Nunes R and Rego G, "Euthanasia: A Challenge to Medical Ethics," Clinical Research \& Bioethics 7, no. 4 (2016): 1-5.
}

Prinsip Kepercayaan Hidup, dalam Islam manusia dipercaya untuk melindungi hidup mereka yang diberikan kepada mereka dan dengan demikian, wajib bagi mereka untuk melindungiitu. Karenanya Nabi melarang ibadah yang dapat membahayakan kesehatan manusia. Prinsip Tanggung Jawab, melindungi integritas tubuh dan jiwa ( nafs, ruh) adalah salah satu tanggung jawab utama orang beriman dengan hukum Islam. Mereka yang tidak melindungi jiwa mereka tidak akan memenuhi kewajiban mereka baik kepada Allah, ataupun kepada manusia dan makhluk lain. Selain itu, mereka tidak dapat memenuhi tugas pembangunan bumi itu diberikan kepada mereka. Jika tidak ada manusia, semua hal lain kehilangan artinya. Dengan demikian, manusia harus melindungi integritas tubuh dan jiwa. Prinsip bahwa kehidupan manusia adalah nilai dasar, hukum Islam menambahkan "kehidupan" pada hal-hal yang harus benar-benar dilindungi, seperti agama, akal, generasi dan Properti. Prinsip bahwa hak hidup tidak dapat dilepaskan,dalam hukum Islam, manusia tidak dapat bunuh diri dengan tangannya sendiri, atau dengan bantuan orang lain. Prinsip dimana tidak seorang pun memiliki otoritas untuk memiliki watak kehidupan, bahkan jika mereka memiliki kemauan parsial ( irada juqiyya), hukum Islamtidak memberikan hak kepada orang beriman untuk memiliki disposisi hidup mereka. Hal ini karena pengetahuan tentang kelahiran dan 
kematian hanya milik Allah. Prisip bahwa keinginan untuk mati adalah keinginan yang bertentangan dengan psikologi manusia, psikolog terkenal Freud pernah berkata,

"tidak ada yang percaya mereka akan mati, kesadaran kita beroperasi seolah-olah kita adalah abadi".

Dengan kata-kata ini, ia menarik perhatian pada sisi psikologis manusia. Dalam Al-Quran, benar menekankan bahwa, bahkan mereka tahu bahwa tidak ada jalan keluar dari kematian, dalam beberapa kasus manusia menolak kematian dan tidak ingin mengingatnya . Untuk alasan itu, keinginan untuk euthanasia tidak normal dan umumnya disebabkan oleh keputusasaan muncul dari rasa sakit yang tak tertahankan. Meskipun demikian, "putus asa" dan "bunuh diri" adalah perilaku non-Islam. ${ }^{20}$

\section{KESIMPULAN}

Praktik euthanasia sebagai perkembangan ilmu pengetahuan du bidang kedokteran menimbulkan berbagai pro dan kontra dari berbagai sudut pandang. Hal tersebut menjadi pertanda bahwa perkembangan IpTek harus diiringi juga dengan perkembangan etika dan moral agar perkembangan IpTek benar-benar memberikan kemaslahatan bagi manusia. Mengenai euthanasia dalam kedokteran, pihak medis harus

${ }^{20}$ Ali Kaya, "Euthanasia in Islamic Law With Respect to the Theory of Protecting Integrity of Body and Soul," International Jurnal of Humanities and Social Science 2, no. 21 (2012): 292-297. memahami ketentuan-ketentuan yang terdapat dalam kode etik kedokteran. Misal peraturan tentang kewenangan pihak medis, syarat-syarat yang harus terpenuhi sebelum melakukan tindakan euthanasia dan larangan pihak medis dalam membantu mengakhiri kehidupan pada kasus tertentu. Dalam pandangan moral kemanusiaan, euthanasia terkesan sebagai tindakan yang tidak bermoral bagi masyarakat Indonesia yang berasaskan pancasila dengan sila pertamanya yaitu ketuhanan yang Maha Esa. Meskipun praktik euthanasia telah legal di negara-negara lain dengan mengatasnamakan pembebasan dari penderitaan. Berdasarkan perspektif hukum Islam tindakan euthanasia aktif merupakan suatu tindakan yang disamakan dengan pembunuhan berencana. Hal itu dilarang dalam hukum syara' dan merupakan pelanggaran hak Allah SW'T yang kehidupan dan kematian makhluk ada dalam kuasa-Nya. Sedangkan euthanasia pasif yang merupakan tindakan penghentian pengobatan atau tidak memberikan pengobatan para ulama' berbeda pendapat karena mengobati atau berobat dari penyakit tidak wajib hukumnya. Tetapi, islam mengajarkan untuk memelihara dan menjaga sesuatu yang kita miliki karena termasuk jiwa kita. Karena semua merupakan titipan dari Allah SWT dan akan kembali kepada-Nya. 


\section{DAFTAR KEPUSTAKAAN}

\section{Buku satu Penulis}

Achadiat. Eutanasia Yang Semakin Kontroversial. Jakarta: Terajana, 2002.

Ahmad, Hanafi. Asas-Asas Hukum Pidana Islam, 1967.

Anwar, Moch. Hukum Pidana Bagian Khusus (KUHP Buku II). Bandung: Alumni KP, 1979.

Chazawi, Adami. Kejahatan Terbadap Tubub Dan Nyawa. Jakarta: PT. Raja Grafindo Persada, 2001.

Djazuli. Fikih Jinayah, Upaya Menanggulangi Kejahatan Dalam Islam. Jakarta: PT. Raja Grafindo Persada, 1997.

Gibtiah. Fikih Kontemporer. Jakarta: Kencana, 2016.

—. Fikib Kontemporer. Jakarta: Kencana, 2016.

Halim. Hukum Pidana Syariah Islam Menurut Ajaran-Ablusunnah. Jakarta: Bulan Bintang, 1971.

Qordlawi, Yusuf. Fatwa-Fatwa Kontemporer. Jilid 2. Jakarta: Gema Insani Press, 2002.

Taimiyah, Ibnu. Al-Fatawa Al-Kubra. Juz 4. Kairo: Mathbah Kurdistan al-Ilmiah, n.d.

Tengker, F. Mengapa Euthanasia? Kemampuan Medis Dan Konsekuensi Yuridis. Bandung: Nova, 1990.

Utomo, Setiawan Budi. Fiqih Aktual. jakarta: Gema Insani Press, 2003.

Fiqih Aktual. Jakarta: Gema Insani Press, 2003.

Vandestra, Muhammad. Hukum Bunuh Diri Dan Eutanasia Dalam Syariah Islam. Copyright, 2018.

\section{Dua Penulis}

M. Yusup, dan Amri Amir. Teknologi Kedokteran Dan Tantangannya Terhadap Biotika. Jakarta: Gramedia Pustaka Utama, n.d.

3. Empat atau lebih Penulis

Indar, Muh.Alwy Arifin, A. Rizki Amelia, and Leilani Ismaniar. Hukum \& Bioetik Dalam Perspektif Etika Dan Hukum Kesehatan. Yogyakarta: Deepublish, 2019.

Kesehatan, Direktorat Jenderal. Kode Etik Kedokteran Indonesia. Jakarta: Departemen Kesehatan, 1983.

\section{Artikel Jurnal}

Ayuba, Mahmud Adesina. "Euthanasia: A Muslim’s Perspective.” Scriptura, 2016, 1-13.

Kaya, Ali. "Euthanasia in Islamic Law With Respect to the Theory of Protecting Integrity of Body and Soul." International Jurnal of Humanities and Social Science 2, no. 21 (2012): 292-97.

R, Nunes, and Rego G. "Euthanasia: A Challenge to Medical Ethics." Clinical Research \& Bioethics 7, no. 4 (2016): 1-5. 